\title{
FURTHER STUDIES ON THE DISTRIBUTION AND ACTIVITIES OF CERTAIN GROUPS OF BACTERIA IN CALIFORNIA SOIL COLUMNS.
}

BY

\author{
CHARLES B. LIPMAN
}

More than six years ago I prepared for publication, and soon thereafter published ${ }^{1}$ some results of certain of my studies on the bacteria of California "soil columns." In that paper I pointed out that by dint of the somewhat laborious Remy method I concluded that "arid" soils behave differently from "humid" soils in respect to certain groups of their bacterial flora, in that among other things active bacterial growth seems to go on at relatively great depths in the first class of soils and only at shallow depths in the second. Much has transpired since that statement appeared which has contributed to extensive changes in science in general and in soils science in particular. Positive facts and logic have been presented which have shaken to their foundations some of the most dearly cherished and firmly established concepts of a former generation. The fate of vast accumulations of data on soils hangs in the balance, if, indeed, their doom is not already sealed. All of that has perforce altered or is altering the objectives of soil work generally, and has exerted a profound influence on the determination regarding the validity and significance of the plans, purposes, and results of the investigations from which the present study emanated.

To introduce properly and to justify what follows, if such justification be needed, it may not be amiss to make brief reference to what might be termed the parent investigations from which the bacteriological studies in question sprang, and particularly of the

1 Lipman, C. B., The distribution and activities of bacteria in soils of the arid region, Univ. Calif. Publ. Agri. Sci., vol. 1, pp. 1-20, 1912. 
present status of their results and the effect of these results on the investigations described in this paper.

For many years, and especially during the last fifteen years of their lives, the late Professors Hilgard and Loughridge carried out mechanical and chemical analyses on what they termed the soil columns of California. These soil columns, which are now represented in their entirety in our collections, were series of soil and subsoil samples of what Hilgard and Loughridge regarded as the most typical soil classes in the state and particularly those typifying the arid soil conditions. To obtain these samples a type of post-hole auger, manufactured by Iwan Brothers, at South Bend, Indiana, was employed, with special extensions made for our use in boring at considerable depths. A sample, representing an average of every foot in depth, was usually taken down to and including the twelfth foot wherever ground water, thick hardpan, or similar obstacles did not interfere. If such obstacles were encountered the samples were taken as deeply as possible. Thus, while in most cases the columns represented twelve feet of soil in depth there were a number representing only four, six, or seven feet. The mechanical analyses were carried out by the Hilgard elutriator method, and the chemcial analyses by the Hilgard strong-acid digestion method. The ultimate object of this work was to construct a map showing the important soil classes of California as then regarded, and, by giving information on the mechanical and chemical constitution of the soils, to enable the farmer to understand the physical and chemical suitability, or incompatibility of his soil for given crops, as well as their dependence on, or independence of fertilization.

To render his data more complete, and incidentally to throw some light on the microörganisms of arid soils, which at that time was practically an untouched field, Hilgard invited the writer more than a decade ago to begin a study of the bacteria of arid soils and to include in such study the soil columns of California. Recent studies in my laboratory, carried out by one of my associates, Dr. D. D. Waynick, have shown what we have been suspecting for the last four or five years, the hopelessness of Hilgard and Loughridge's plan. The reasons for this may be briefly stated as follows:

1. Soils are so markedly variable that a column collected in one spot cannot be considered representative of anything. Even a composite sample of truly representative nature is practically impossible to obtain. 
2. A mechanical analysis gives no idea of the actual arrangement of the soil particles in situ; hence it is only the crudest kind of guide to the soil's physical characters.

3. The chemical analyses were carried out by an arbitrary method; but this in itself would not be so serious if any true correlation had ever been made between a soil's chemical composition and its cropproducing power. This has thus far not been done; besides, the analytical method in question was perhaps the least likely to figure in such a correlation if it should be attained. Moreover, the first point made above wholly negatives the validity and utility of analytical results obtained on such samples and by such methods as those under consideration.

Necessarily these fallacies were bound to affect the bacteriological studies, and many of the results as well as those of the chemical and mechanical analyses are now resting in the obscurity which they deserve. However, one outcome at least of the bacteriological studies possesses a scientific and perhaps also a practical value; that is, the determination of the depths to which microörganisms penetrate in arid soils and at which they are probably active. As pointed out in the opening lines of this paper, some of the results obtained in work on that problem have already been published. Further results would have been published if the method involved had not been so laborious. Recently, however, we have found by a careful investigation that for all practical purposes the auger-collected samples are just as good in every way as those collected by the special and laborious method which I devised ten years ago. The results of comparative tests of these two methods are given in a recent paper ${ }^{2}$ by D. E. Martin and the writer. The fact that the auger-collected samples are just as reliable as those collected with special and great precautions, made possible the collection of ten more soil columns to a depth of six feet, inclusive. The results of studies on these additional soil columns form the chief topic of this paper, and are published primarily for the purpose of showing that bacteria and other microörganisms may penetrate to a depth of at least seven feet in most, if not in all arid soils. No other significance is claimed for the data submitted.

2 Lipman, C. B., and Martin, D. E., Are the usual precautions necessary in taking soil samples for bacteriological tests? Soil Science, vol. 6, no. 2, p. 131, August 19, 1918. 


\section{Plan of Procedure}

The samples were taken by Mr. D. E. Martin with the Iwan post-hole auger. The detailed method of sampling is given in the paper cited above. The samples were shipped to the laboratory in tight Mason fruit jars. The locations at which the samples were collected are as follows :

No. 1, Roseville.-Three hundred yards due west of high school; fifty feet east of southeast corner of new city park; old grain field; Bureau of Soils classification, San Joaquin sandy loam. Decomposed hardpan, two feet to two feet six inches, and clayey material below.

No. 2, Wheatland.-One hundred and fifty yards southwest of Southern Pacific station; ten yards west of highway in young peach orchard, on edge of high ground. Bureau of Soils classification, Aiken fine sandy loam.

No. 3, Gridley.-One hundred yards northwest of Southern Pacific station; twenty yards north of main street; middle of block in vacant lot; water table at five feet. Bureau of Soils classification, Hanford sandy loam.

No. 4, Marysville.-One hundred yards east of highway; one-half mile south of Marysville viaduct; Yuba River bottomland; ten feet elevation; bean field; highly productive. Bureau of Soils classification, Columbia silt loam.

No. 5, Grass Valley.-From apple orchard; head of Auburn Street (north end), Grass Valley; residual from granite. Bureau of Soils classification, Sierra clay loam.

No. 6, Davis.-From University Farm at Davis. Bureau of Soils classification, Yolo silt loam.

No. \%, Modesto.-Twenty yards west of highway; one hundred yards north of warehouse Modesto Fuel Company; northern outskırts of town of Modesto. Fresno fine sandy loam, brown phase.

No. 8, Fresno.-Southeast corner of Harvey and Blackstone avenues, East Fresno; vacant lot. Bureau of Soils classification, Madera sandy loam.

No. 9, San Gabriel.-Ten yards east of San Gabriel highway; one-half mile north of junction with El Monte Road (Valley Boulevard); strawberry patch. Bureau of Soils classification, Hanford fine sandy loam.

No. 10, Pasudena.- Twenty yards west of Orange Grove Avenue; ten yards south of Pasadena Avenue (southwest corner); orange grove. Bureau of Soils classification, Placentia sandy loam. 
The tests made on the soils consisted of the usual ammonification, nitrification, and nitrogen fixation determinations, with no pretense at attaching importance to the absolute values obtained. All the tests were made in the well known soil cultures in tumblers. For the ammonification tests, one gram of dried blood was mixed with fifty grams of soil and incubated for seven days under optimum temperature and moisture conditions. For the nitrification tests, one hundred grams of soils were used in every culture, the cultures being arranged in three ways, viz., soil alone, soil plus $1 \%$ dried blood, soil plus $.2 \%$ ammonium sulphate. The incubation period was one month under the usual conditions of moisture and temperature. For the nitrogen fixation test, fifty-gram portions of soil were employed with $1 \%$ of mannite. The incubation period was three weeks, at optimum moisture and temperature conditions. The results of these tests are given in the accompanying tables. Only averages of the determinations are given in the tables, for two reasons. In the first place, the duplicates agreed closely in most cases; in the second place, no special importance, as already indicated above, needs to be attached for our purposes to the absolute figures. For simplicity and convenience we shall discuss briefly each table separately.

\section{The Ammonification Results}

The data obtained and given in table 1 speak for themselves. There is every indication in them that ammonia-producing organisms, including both bacteria and fungi are active at considerable depths in all the soils. Indeed, there is little indication in our results that the ammonifying activities of the soils studied are inferior below six feet to those above six feet. That the uniformly high, bacterial efficiency at ammonia production is not the result of contamination of one soil layer by another had already been proved in the paper above cited, ${ }^{2}$ and is proved again in the nitrification table accompanying this paper. In other words, we seem to be justified in accepting as definitely proved the fact that microörganisms, in arid soils do penetrate to considerable depths; particularly is this true of the ammoniaproducing organisms, which in the soils here studied show about as great an efficiency in the sixth as in the first foot in depth. 


\section{The Nitrification Results}

A study of table 2 reveals at once the great differences characterizing the ammonifying and nitrifying powers of the ten soils studied in this investigation, and especially below the first foot in depth. While it is impossible in table 1 to find indisputable evidence that the ammonifying power of any of the soils decreases downward from the surface foot, the evidence is more than ample in regard to nitrification in table 2. In practically every case the surface foot of soil is not only superior but usually far superior to those below it in efficiency at nitrate production. The contrast is indeed very striking. The data help, moreover, in proving that the method of sampling employed is justifiable and valid. Despite all this, however, table 2 gives unquestionable evidence in support of the idea that even nitrifying organisms do penetrate as far down as the seventh foot of soil under arid conditions. While their work may be feeble in many arid soils at considerable depths it is quite vigorous in many others at similar depths. Such activity is manifested regardless of the form of nitrogen available for nitrification. As a rule, it appears that the more fertile soils, like those at Gridley and Davis, are those in which bacterial activity is greatest in the deeper layers. Owing to the organic matter supply in such soils, contrasted with that in the poorer soils, like those at Fresno and Modesto, it is natural that the bacterial efficiency should vary accordingly, which, indeed, is just as true in the surface foot of soil as in the deeper layers.

\section{The Nitrogen Fixation Results}

The nitrogen fixation results are given in table 3 . They cannot be regarded as being of much significance, owing to the considerable error which attaches to a nitrogen determination on a ten-gram portion of soil. The determinations were made in duplicate, but only the averages are given in the table; these represent five times the quantity of nitrogen found in ten grams of the soil culture, minus the amount found in the sterile control portion taken for analysis. It is easy to see that such manipulation may easily lead to serious errors. However that may be, the results are given for whatever interest and value they may possess. In the case of the San Gabriel soil, it is probably true that the figures represent actual gains in nitrogen, and it is interesting to note that while nitrogen fixation in 
this soil is less in the lower than in the upper layers, it seems to be quite definite. From this soil, at least, it would appear that the nitrogen fixation results are in general accord with the ammonification and nitrification results regarding the chief point made in this paper, viz., that bacterial life does extend into the deeper layers of the soil under arid conditions. Through an oversight the Pasadena soil was not studied in regard to nitrogen fixation, hence no statement appears with regard thereto in table 3 .

\section{Summary and Conclusion}

From studies on twelve soils, two of which are discussed in another paper and ten in this paper, the writer has been able to confirm his findings of several years ago to the effect that microörganisms of arid soils penetrate deeply into the subsoil layers.

In the present paper it has been demonstrated that ammonifying vigor continues undiminished through six feet of soil in every case. While this is not true for the nitrifying powers of the same soils, it is clear that nitrifying bacteria do live in the lower layers of some, and perhaps of all of the soils to similar depths. The great difference between the two, however, lies in the fact that the nitrifying power of these soils diminishes rapidly downward from the first foot while the ammonifying power remains apparently unchanged. The nitrogen fixation results are for the most part inconclusive, but such as are above question seem in general to confirm the idea that bacteria and other microörganisms do penetrate to greater depths in arid soils than one would expect. Such penetration and activity at those depths seem to be superior to those noted on humid soils, so far as we have evidence in the literature upon which to base such a comparison.

TABLE 1.-AMMONIFication

Milligrams of Nitrogen as Ammonia Produced

\begin{tabular}{|c|c|c|c|c|c|c|}
\hline Name of soil & 1 & 2 & 3 & 4 & 5 & 6 \\
\hline Roseville .......... & 30.84 & 31.89 & 29.17 & 10.00 & 22.12 & 20.79 \\
\hline Wheatland ...... & 35.84 & 39.13 & 32.60 & 28.27 & 28.00 & 22.96 \\
\hline Gridley ........... & 38.22 & 32.20 & 36.96 & 30.80 & 22.82 & 14.49 \\
\hline Marysville ....... & 33.81 & 34.79 & 35.28 & 38.65 & 36.33 & 36.96 \\
\hline Grass Valley .... & 23.10 & 24.50 & 20.30 & 22.96 & 23.94 & 21.63 \\
\hline Davis & 68.18 & 54.88 & 44.94 & 37.66 & 40.60 & 41.58 \\
\hline Fresno ................. & 38.71 & 38.64 & 37.03 & 36.54 & 33.74 & 30.52 \\
\hline Modesto ................. & 38.71 & 42.63 & 40.18 & 39.48 & 42.14 & 41.40 \\
\hline San Gabriel ...... & 42.14 & 38.57 & 50.22 & 38.36 & 37.24 & 32.34 \\
\hline Pasadena ........ & 56.35 & 52.64 & 46.34 & 52.71 & 41.93 & 18.18 \\
\hline
\end{tabular}




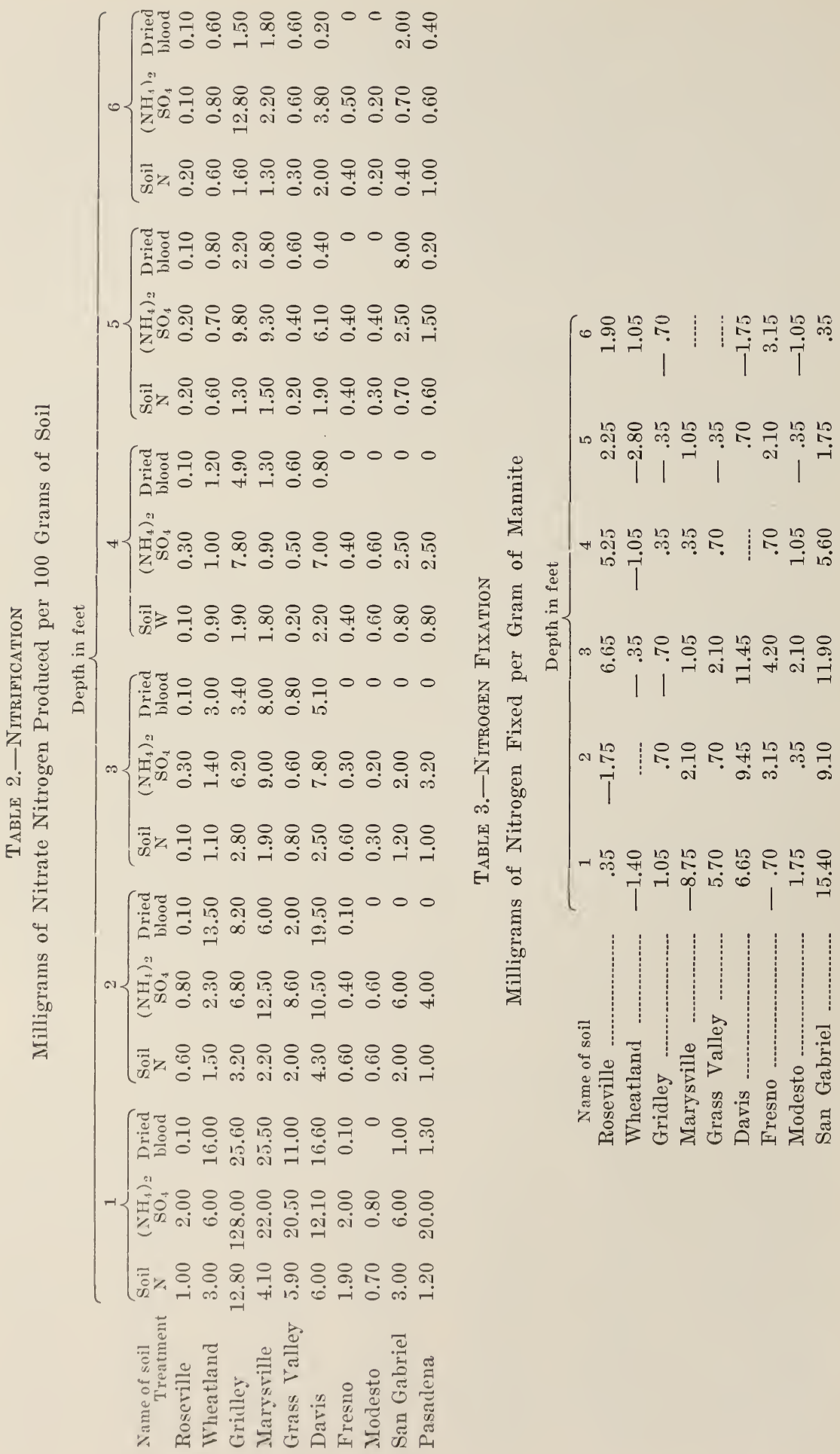

